Original Research

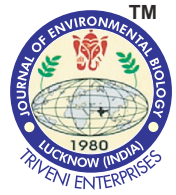

DOI : http://doi.org/10.22438/jeb/39/4/MRN-546

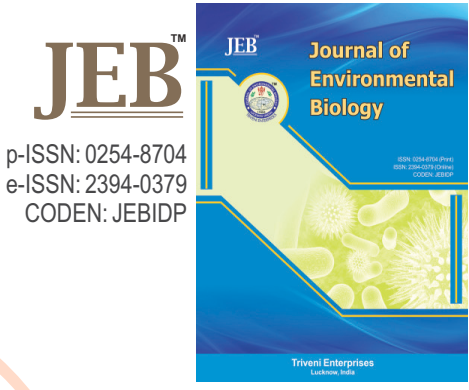

\title{
Diversity assessment in Abelmoschus tuberculatus : A DIVA-GIS study
}

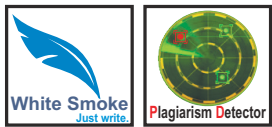

Authors Info

D. Chand ${ }^{1 *}$, N. Dikshit', N. Sivaraj', S.S. Gomashe ${ }^{1}$ and M.A. Nizar ${ }^{1}$

${ }^{1}$ ICAR-National Bureau of Plant Genetic Resources, Regional Station, Dr. PDKV Campus, Akola-444 104, India

${ }^{2}$ ICAR-National Bureau of Plant Genetic Resources, Regional Station, Rajendranagar, Hyderabad-500 030, India

*Corresponding Author Email : nbpgrakl@yahoo.com

Key words

Biotic stress tolerance DIVA-GIS

Genetic Diversity

Resistance sources

Wild Okra

Publication Info

Paper received : 23.12 .2016

Revised received : 26.08.2017

Re-revised received : 04.11.2017

Accepted:02.12.2017

\section{Abstract}

Aim : Variability in Abelmoschus tuberculatus Pal \& Singh from North Western, Central Indian and its adjoining regions has not been studied for agro-morphological traits. Considering the importance of this wild species as a donor for desirable traits, the study was carried out to assess the diversity for increasing its utilization in okra breeding programmes.

Methodology : Fifty eight accessions of wild okra were grown in an augmented block design during the kharif seasons of 2014-15 and 2015-2016 at Akola, India. Nine qualitative and ten quantitative traits were recorded. Data-Interpolating Variational Analysis-Geographic Information System (DIVA-GIS) version 7.5 and SAS Enterprise Guide 4.3 were used for diversity and statistical analyses, respectively.

Results : Significant variability was observed in qualitative and quantitative traits. High coefficient of variation was observed in fruits per plant $(52.56$ $\%)$ followed by first fruit producing node $(46.03 \%)$, first flowering node $(43.8 \%)$ and number of seeds per fruit (38.82) suggesting existence of diversity for these traits. Dendrogram (Wards method) articulated two clusters comprising 21 and 37 genotypes, respectively. DIVAGIS grid maps generated for diversity analysis in $A$. tuberculatus indicated that the Central Indian region was diversity rich pocket. Shannon diversity index and coefficient of variation values for plant height, days to maturity, number of fruits

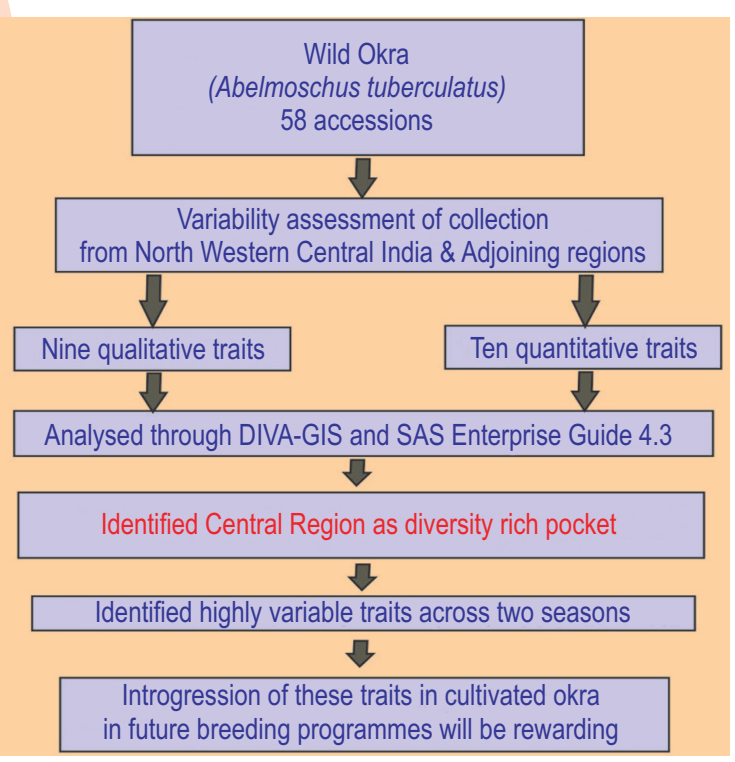
per plant, fruit length, number of seeds per fruit and 100 seed weight indicated Central region of Maharashtra as potential region for diversity of these traits.

Interpretation : DIVA-GIS analysis revealed that Central Maharashtra, Gujarat and Madhya Pradesh, are diversity rich pockets for wild okra (A. tuberculatus) germplasm in fruit traits. The desirable traits viz., resistances to pest and diseases identified in $A$. tuberculatus may be worth introducing into the cultivated species in future okra improvement programmes. 


\section{Introduction}

The Indian sub-continent is an important centre of diversity for both wild and cultivated okra. Abelmoschus esculentus (L.) Moench and A. caillei (L.) are the two cultivated species and grown in many parts of the world, especially in tropical and sub-tropical countries. Various wild Abelmoschus species occurring around the world are $A$. angulosus Wall. Ex Wight \& Arn., A. crinitus Wall., A. ficulneus (L.) Wight \& Arn., A. moschatus Medik., A. manihot (L.) Medik. ssp. tetraphyllus (Roxb. Ex Horneum) and A. tuberculatus, (Charrier, 1984). The geographical distribution of cultivated and wild species of genus Abelmoschus, clearly shows overlapping in South East Asia, which is considered as the centre of diversity (Van Borssum Waalkes, 1966; Charrier, 1984).The genus Abelmoschus Medik, originated in South-East Asia (Hochreutiner, 1924). A. esculentus (L.) Moench (commonly known as Lady's finger, okra or bhindi), and is grown extensively, throughout the country. A number of wild Abelmoschus species are found in nature in different phytogeographical regions from Himalayas to the Southern parts of India in dense forests, open waste lands, as well as road side and also backyard gardens. A. tuberculatus is more closely related to $A$. esculentus than other species and differs from it by the strigose pubescence on the stem and shorter capsule with bristly tuberculate hair (Pal et al., 1952). The wild relatives of Abelmoschus have been identified as potential sources of desirable genes for agronomic traits such as biotic and abiotic stresses which can be useful in okra breeding programme (Gangopadhyay et al., 2017).

Traditional breeding approach is the only way to transfer the desired genes from wild relatives to the modern cultivar. $A$. tuberculatus is regarded as one of the ancestral species from which $A$. esculentus have been originated. Cytological evidences confirming chromosome homology during meiotic phase in case of hybrids between $A$. esculentus and $A$. tuberculatus revealed that out of 65 chromosomes of $A$. esculentus $(n=65)$ about 29 exhibited complete homology with 29 that of $A$. tubeculatus ( $n=29)$ (Joshi et al., 1974).

Indian Council of Agricultural Research-National Bureau of Plant Genetic Resources (ICAR-NBPGR) is the nodal organization in India for Plant Genetic Resources (PGR) activities with the national mandate for collection, characterization, evaluation, maintenance and conserving germplasm of agrihorticultural crops and their wild relatives. Variability in Abelmoschus species genetic resources has been built up in NBPGR over the last four decades, both by undertaking explorations within the country and through introduction of promising material from other countries. Though variability in wild species has been collected (Velayudhan et al., 1996; Negi and Pant 1998, AdeOluwa and Kehinde, 2011; Nizar et al., 2014 and Gangopadhyay et al., 2017), there is an urgent need to collect more diversity in the case of Abelmoschus wild species so as to fill the gaps identified and conserve the gene pools.
Variability from North Western, Central Indian and its adjoining regions has not been studied for agro-morphological and biotic stresses. Hence, there is an urgent need to study the diversity pattern in $A$. tuberculatus germplasm and to identify key traits and diversity rich areas for using in crop improvement programmes. This has direct advantage for increasing its utilization for introgressing valuable genes.

\section{Materials and Methods}

A total of 58 accessions were used in the present study (Table1). All the accessions were sown during the Kharif seasons of 2014-15 and 2015-16 at ICAR-NBPGR, Regional Station, Akola (Maharashtra). The soil at experimental field is vertisol derived from basalt rocks. The area is semi-arid with an average annual rain fall of 750 to $900 \mathrm{~mm}$, from South-West monsoon received during June to September months. The minimum and maximum temperature ranged between $30^{\circ}$ to $48^{\circ} \mathrm{C}$ during the growing season. The experiment was conducted in an augmented block design with $0.90 \mathrm{~m} \times 3.0 \mathrm{~m}$ crop geometry. All the recommended agronomic practices were followed. Observations were recorded on nine qualitative traits (plant vigour, growth habit ,branching habit, number of epicalyx segment, shape of epicalyx segment, immature fruit colour, fruit pubescence, mature fruit colour and number of ridges per fruit) and ten quantitative traits (days to $50 \%$ flowering, plant height $(\mathrm{cm})$, days to $80 \%$ maturity, first flowering node, first fruiting node, fruit length $(\mathrm{cm})$, fruit width $(\mathrm{mm})$, number of fruits per plant, no of seeds per fruit, and seed weight). The data recorded over the two years were combined and means were calculated for each accession. Statistical analysis software, SAS Enterprise Guide 4.2 was used for statistical analyses. Diversity analysis involving geographical information system (DIVA GIS version 7.5) was carried out using freely downloadable DIVA-GIS software from www.diva-gis.org (Hijmans et al., 2012).

\section{Results and Discussion}

The major factors promoting diversification in the crop plants are the adopted farming systems by farmers mainly based on rainfall and soil regimes which create diverse agroclimatic conditions. This has resulted in the crop diversification in the South East Asia. India with very diverse agro-climates is major habitat for different Abelmoschus species which are present under different gene pools (wild, semi-wild and cultivated) (Patil et al., 2015).

All the accessions were erect in growth habit, low in branching habit, epicalyx ranged from 8-10 and number of ridges per fruit ( 5 to 7 ), linear epicalyx, immature fruit colour was green, fruit pubescence slightly rough. Early plant vigour expression was very good in (58.62\%), good $(31.04 \%)$, and poor in $(10.34 \%)$ accessions. Significant variability was observed for quantitative traits within the accessions studied (Table 2). Plant height varied from $35.75 \mathrm{~cm}$ ( IC 40964) to 
Table 1 : Passport information of Abelmoschus tuberculatus germplasm

\begin{tabular}{|c|c|c|c|c|c|c|c|c|c|}
\hline S.N. & IC Nos. & Place of Collection & District & State & S.N. & IC Nos. & Place of Collection & District & State \\
\hline 1 & IC 90311 & Koduwa & Rajkot & GJ & 30 & IC 140984 & Erandol & Jalgaon & MS \\
\hline 2 & IC 90324 & Bagasra & Amreli & GJ & 31 & IC 140987 & Akola & Akola & MS \\
\hline 3 & IC 90328 & Amreli & Amreli & GJ & 32 & IC 140990 & Balapur & Akola & MS \\
\hline 4 & IC 90340 & Bareja & Ahmedabad & GJ & 33 & IC 140991 & Balapur & Akola & MS \\
\hline 5 & IC 90359 & Surat & Surat & GJ & 34 & IC 140998 & Bharasa & Buldana & MS \\
\hline 6 & IC 90363 & Gurukul & Surat & GJ & 35 & IC 141026 & Manor & Thane & MS \\
\hline 7 & IC 90376 & Dabhoi & Baroda & GJ & 36 & IC 141036 & Lakshanareddy & Rangareddy & $\mathrm{TL}$ \\
\hline 8 & IC 90378 & Dabhoi & Baroda & GJ & 37 & IC 415749 & Amravati & Amravati & MS \\
\hline 9 & IC 90380 & Gotia & Baroda & GJ & 38 & IC 467696 & Buldana & Buldana & MS \\
\hline 10 & IC 90381 & Gotia & Baroda & GJ & 39 & IC 467699 & Buldana & Buldana & MS \\
\hline 11 & IC 90387 & Panamb. & Panch mahal & GJ & 40 & IC 467729 & Jalgaon & Jalgaon & MS \\
\hline 12 & IC 90389 & Balwada & Dungerpur & GJ & 41 & IC 549851 & Akola & Akola & MS \\
\hline 13 & IC 90396 & Mandsaur & Mandsaur & MP & 42 & IC 549881 & Yavatmal & Yavatmal & MS \\
\hline 14 & IC 90400 & Khyasura & Jhalawar & RJ & 43 & IC 550642 & Akola & Akola & MS \\
\hline 15 & IC 90402 & Jhalawar & Jhalawar & RJ & 44 & IC 550645 & Akola & Akola & MS \\
\hline 16 & IC 90407 & Near Bijolia & Bhilwara & RJ & 45 & IC 550647 & Washim & Washim & MS \\
\hline 17 & IC 140941 & Mangliawas & Ajmer & RJ & 46 & IC 550651 & Washim & Washim & MS \\
\hline 18 & IC 140942 & Gadrela & Kota & RJ & 47 & IC 550654 & Washim & Washim & MS \\
\hline 19 & IC 140949 & Dagoudi & Tikamgarh & MP & 48 & IC 550656 & Hingoli & Hingoli & MS \\
\hline 20 & IC 140954 & Gochipura & Tikamgarh & MP & 49 & IC 550657 & Hingoli & Hingoli & MS \\
\hline 21 & IC 140955 & Brijpura & Chattarpur & MP & 50 & IC 550662 & Hingoli & Hingoli & MS \\
\hline 22 & IC 140956 & Jagpura & Chattarpur & MP & 51 & IC 550681 & Parbhani & Parbhani & MS \\
\hline 23 & IC 140957 & Jagpura & Chattarpur & MP & 52 & IC 550684 & Latur & Latur & MS \\
\hline 24 & IC 140962 & Chanua & Damoh & MP & 53 & IC 550685 & Latur & Latur & MS \\
\hline 25 & IC 140963 & Sanondha & Damoh & MP & 54 & IC 550687 & Nanded & Nanded & MS \\
\hline 26 & IC 140964 & Gader & Guna & MP & 55 & IC 550759 & Buldana & Buldana & MS \\
\hline 27 & IC 140965 & Pachor & Rajgarh & MP & 56 & IC 550765 & Buldana & Buldana & MS \\
\hline 28 & IC 140969 & Kanvan & Dhar & MP & 57 & IC 550768 & Buldana & Buldana & MS \\
\hline 29 & IC 140970 & Echhapur & Khandwa & MP & 58 & IC 550775 & Buldana & Buldana & MS \\
\hline
\end{tabular}

GJ: Gujarat, MP: Madhya Pradesh, MS: Maharashtra, RJ: Rajasthan, TL: Telangana

Table 2 : Variability observed for different traits in wild okra germplasm

\begin{tabular}{lllllllllll}
\hline & DFL & MAT & FFLD & FFRD & PHT & FRLT & FRPLT & FRWD & SEDFRUT & SWT \\
\hline Minimum & 57.00 & 91.00 & 1.00 & 1.00 & 35.75 & 2.50 & 2.80 & 9.58 & 3.60 & 1.21 \\
Maximum & 91.00 & 122.00 & 7.00 & 7.20 & 173.60 & 6.78 & 19.80 & 17.40 & 72.00 & 3.31 \\
Mean & 73.79 & 105.95 & 3.47 & 3.54 & 117.98 & 5.21 & 8.28 & 13.20 & 39.91 & 2.28 \\
Standard Error & 1.07 & 1.13 & 0.20 & 0.21 & 4.14 & 0.11 & 0.57 & 0.20 & 2.03 & 0.05 \\
Standard Deviation & 8.15 & 8.64 & 1.52 & 1.63 & 31.56 & 0.83 & 4.35 & 1.49 & 15.49 & 0.42 \\
Sample Variance & 66.38 & 74.61 & 2.31 & 2.66 & 995.93 & 0.70 & 18.94 & 2.21 & 240.09 & 0.17 \\
Kurtosis & -1.14 & -1.32 & -0.91 & -0.99 & -0.11 & 0.85 & 0.09 & 0.19 & -0.38 & 0.28 \\
Skewness & 0.21 & 0.06 & 0.25 & 0.30 & -0.66 & -0.48 & 0.95 & 0.05 & -0.64 & -0.27 \\
Coefficient of & 11.04 & 8.15 & 43.80 & 46.03 & 26.75 & 16.02 & 52.56 & 11.25 & 38.82 & 18.29 \\
Variation (\%) & & & & & & & & & & \\
\hline
\end{tabular}

DFW- Days to 50\% flowering, MAT- Days to $80 \%$ maturity, FFLD-First Flowering Node, FFRD -First Fruiting node, PHT- Plant height, FRLT- Fruit Length, FRPLT- Fruits Per Plant ,FRWD-Fruit Width, SEDFRUT- Seeds per Fruit, SWT- 100 Seed Weight

$173.60 \mathrm{~cm}$ ( IC 467696 ), days to $50 \%$ flowering from 57 (IC090328) to 91 ( IC550681), days to $80 \%$ maturity ranged 91 (IC090396) to 122 (IC550681), first flowering node varied 1.0 (IC 090407) to 7.0 (IC 550759), first fruiting node 1.0 (IC
090407) - 7.2 (IC140965), fruit length varied from $2.5 \mathrm{~cm}$ (IC140965) to $6.78 \mathrm{~cm}$ (IC140955), number of fruits per plant 2.8 (IC141036) to 19.8 (IC090328), fruit width ranged from 9.58 $\mathrm{mm}$ (IC 549881) to $17.4 \mathrm{~mm}$ (IC140987), number of seeds per 
fruit observed was 3.6 (IC550657) to 72 (IC140955) and seed weight varied from $1.21 \mathrm{~g}$ (IC550681) to $3.31 \mathrm{~g}$ (IC140991). High coefficient of variation was observed in fruits per plant (52.56), first fruit producing node (46.03), first flowering node (43.8), seeds per fruit (38.82) and medium coefficient of variation was observed in plant height (26.75), seed weight (18.29) and fruit length (16.02).

DIVA-GIS is one of the best tool for analysis of diversity which depicts clear scenario about the distribution of diversity over different geographical regions and there by facilitates identification of gaps in the collection of a particular species. Geographic Information System (GIS) mapping provides an effective way to document various genetic resources management activities such as assessing loss of diversity in the species which helps in the development of fast track strategies to conserve and utilize genetic resources in the present context where lots of international developments are happening for food and nutritional security. GIS mapping has been successfully used over the years for assessing biodiversity and in identifying areas of high diversity in Phaseolus bean (Jones et al., 1997). Hijmans and Spooner et al. (2001) used GIS methodology with database of 6073 geo-referenced observations to assess the geographic distribution of wild potatoes and concluded that high number of species were from Peru. Similarly, the diversity in black gram (Vigna mungo L. Hepper) was studied by Abraham et al. (2010) in 163 genotypes collected from 17 districts of Andhra Pradesh. Parthasarathy et al. (2006) used DIVA-GIS for mapping pepper species distribution in India. Varaprasad et al. $(2007,2008)$ used GIS mapping for selected medicinal plants diversity and overall agrobiodiversity in Andhra Pradesh. The DIVA-GIS approach was also successfully used for mapping the prediction from Maxent for modelling the potential geographic distribution of cotton mealybug (Phenacoccus solenopsis) in India (Fand et al., 2014). ÖZKAN et al. (2015) carried out visual assessment of potential distribution probability of applied models for Crimean juniper by using GIS. These studies confirmed the effectiveness of DIVA-GIS analysis in delineating distribution of germplasm over the geographic area. It also facilitates planning of germplasm collection programme for specific traits from the identified regions.

DIVA-GIS grid map generated for the plant height revealed that high Shannon diversity index (1.76-3.0) recorded for A. tuberculatus accessions from Maharashtra state indicating the future germplasm collections for diverse accessions for plant height may be targeted in Maharashtra. Sunil et al. (2008), reported seed yield attributes in horse gram germplasm and subjected to mapping using DIVA-GIS and identified Rayalaseema region harbouring useful variation. However, high diversity index for coefficient of variation observed in several states such as Gujarat, Madhya Pradesh and Maharashtra. High Shannon diversity index ranged from 1.76-3.0 for $A$. tuberculatus accessions sourced from Maharashtra state for the traits days to $80 \%$ maturity; fruits per plant; fruit length; seeds per fruit and

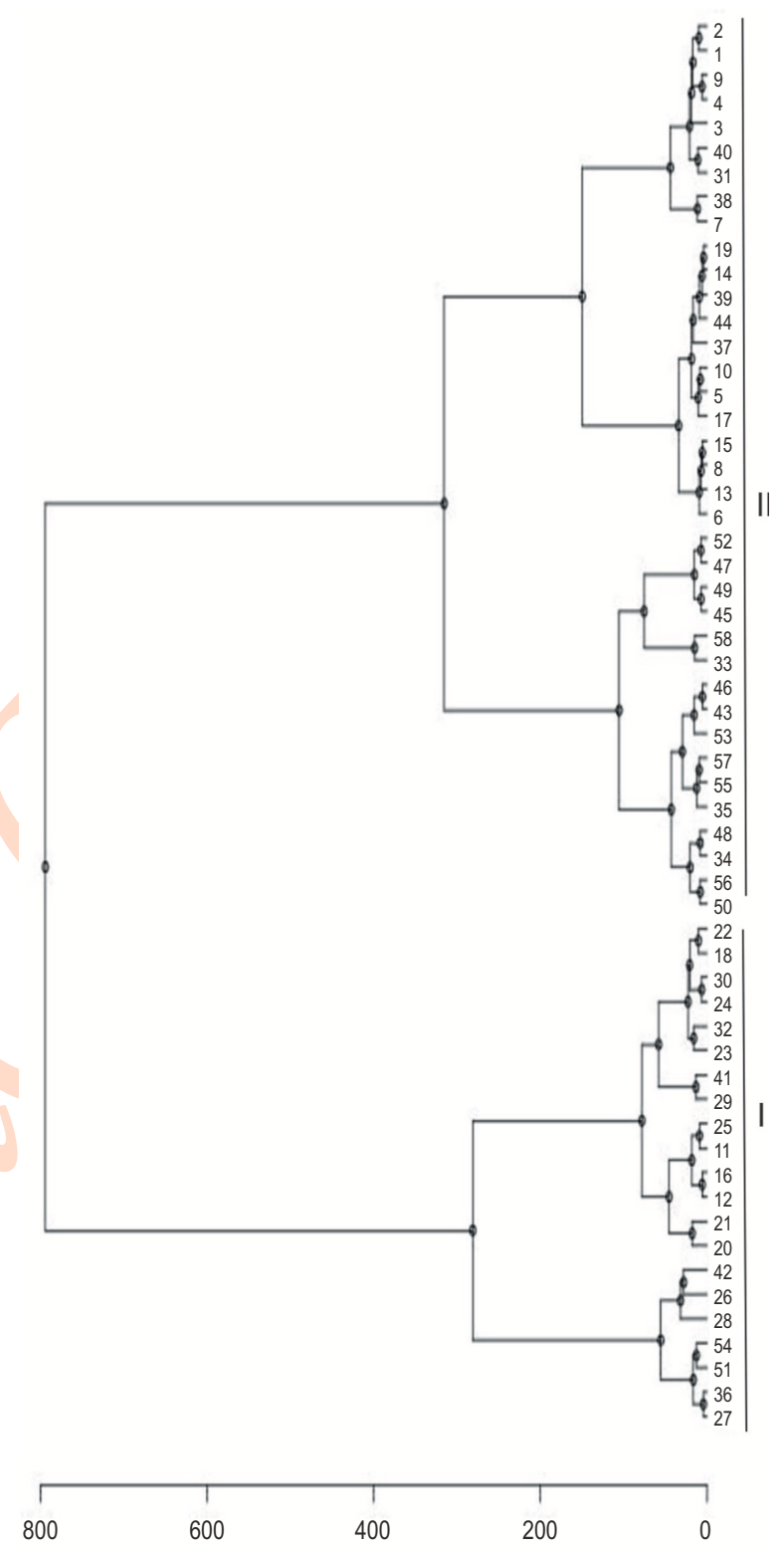

Fig. 1 : Grouping of Abelmoschus tuberculatus germplasm based on Wards Minimum Variances

seed weight indicating that Maharashtra state could be an ideal region for in-situ conservation and for planning future Abelmoschus genetic resources collection missions.

The coefficient of variation (CV \%) recorded for the traits days to maturity (6.0-8.0\%); fruits per plant (42-53\%); fruit length (13.0 - 18.0\%); seeds per fruit (50.0-83.0\%) and seed weight $(21.0-27.0 \%)$ indicated that the diverse accessions are available from Maharashtra and Madhya Pradesh states. Highest CV 
values were recorded for seeds per fruit (upto $83 \%$ ) and fruits per plant (upto 53\%) indicating the occurrence of diverse genetic resources in the wild plant species $A$. tuberculatus. The wild okra germplasm sourced from several Indian states (Gujarat, Rajasthan, Andhra Pradesh, Madhya Pradesh and Maharashtra) was evaluated, and based on evaluation data wards minimum variance dendrogram (Fig. 1) was generated. It grouped $A$. tuberculatus germplasm into two clusters comprising 21 and 37 genotypes indicating that geographical diversity and genetic diversity are not related. Clusters showed distinctness in respect to the characters plant height, fruit length, fruits per plant and seeds per fruit. Genotypes in cluster II recorded higher values for these traits. Genotypes in cluster II viz., IC467696 and IC90376 for plant height; IC550656 and IC140941 for fruit length; IC90328 and IC90324 for number of fruits per plant can act as desirable donors for these traits. From cluster I genotypes, IC550681 and IC550687 can be used for reducing number of seeds in fruits.

The cultivated okra is susceptible to fungal and viral diseases. Genes for resistance to YVMV (Singh et al., 2007; Gangopadhyay et al., 2017) and powdery mildew are available in the wild species of okra viz., A. manihot, A. tetraphyllus, for jassids in A. moschatus and for fruit borer in A. tuberculatus (Srinivasa and Sugeetha, 2001; Singh, et al., 2007). The wild species as such have not been found to be of any commercial importance as vegetables. However, they possess certain useful characters which may be worth introducing into the cultivated species.

The number of controversies happening towards use of advanced genetic engineering tools to develop Genetically Modified (GM) crops in many parts of the world hindering the progress in development of modern high yielding disease and insect resistance varieties. Considering these facts, the breeders have only one way to use crop wild relatives (CWRs) to transfer the alien genes into modern varieties. Abelmoschus tuberculatus can be used as a potential source for transferring YVMV and fruit borer resistance etc. Two characters of this species, stiff hairs and thick pericarp of fruits are very important characteristic and might be partially or wholly responsible for resistance to borers. The heavy bearing nature of $A$. tuberculatus, resistance to fruit borers and also the sterility of hybrids of $A$. esculentus $\times A$. tuberculatus suggest the possibility of utilisation of $\mathrm{F} 1$ hybrids as such, as new seedless varieties (Pal et al., 1952). Different wild species of okra viz., A. angulosus, A. manihot and $A$. crinitus are identified as a valuable source for YVMV and powdery mildew disease resistance. (Samarajeeva and Rathnayaka, 2004; Bisht and Bhat, 2006). Other than these, many species of genus Abelmoschus have revealed to have useful genes for biotic and abiotic stresses (Dhankar et al., 2005).

Based on DIVA-GIS analysis, it can be concluded that Central Maharashtra, Gujarat and Madhya Pradesh are diversity rich pockets for wild okra (A. tuberculatus) germplasm in fruit traits. Considering usefulness of Abelmoschus tuberculatus for resistance to sucking pests (White flies and jassids), fruit borers and diseases (Powdery mildew, Fusarium wilt, Alternaria blight and YVMV), it could be effectively used in various okra breeding programmes in the country for introgressing the desired traits into cultivated types.

\section{Acknowledgments}

The authors are thankful to the Director, ICAR-NBPGR, New Delhi and Head, Germplasm Evaluation Division, ICARNBPGR, New Delhi for providing facilities and help.

\section{References}

Abraham, B., V.Kamala, N.Sivaraj, N.Sunil, S.R. Pandravada, M. Vanaja and K.S. Varaprasad: DIVA-GIS approaches for diversity assessment of pod characteristics in black gram (Vigna mungo L. Hepper). Curr. Sci, 98, 616-619 (2010).

AdeOluwa, O.O. and O.B. Kehinde: Genetic variability studies in West African okra (Abelmoschus caillei) Agric. Biol. J. N. Am., 2, 13261335 (2011).

Bisht, I.S. and K.V. Bhat: Okra (Abelmoschus spp.). In : Genetic Resources, Chromosome Engineering and Crop Improvement (Ed.: J. Ram Vegetable Crops). CRC Press, Vol. 3, pp.149-185(2006).

Charrier, A. N.: Genetic resources of the genus Abelmoschus Med.(Okra). Rome, IBPGR, p. 61 (1984).

Dhankar, B.S., J.P. Mishra and I.S. Bisht: Okra: In: Plant Genetic Resources: Horticultural Crops (Eds. : B.S. Dhillon, R.K. Tyagi, S. Saxena and G.J. Randhawa). Narosa Publishing House, New Delhi, pp. 59-74 (2005).

Fand, B. B., M. Kumar and A. L. Kamble: Predicting the potential geographic distribution of cotton mealybug (Phenacoccus solenopsis) in India based on MAXENT ecological niche model. J. Environ. Biol., 35, 973-982 (2014).

Gangopadhyay, K. K. , A. Singh, M. K. Bag, P. Ranjan, T. V. Prasad, A. Roy and M. Dutta: Diversity analysis and evaluation of wild Abelmoschus species for agro-morphological traits and major biotic stresses under the north western agro-climatic condition of India. Genet. Resour. Crop. Evol., 64, 775-790 (2017).

Hijmans, R.J., L. Guarino and P. Mathur.: DIVA-GIS version 7.5, Manual available at www. diva-gis.org (2012).

Hijmans,R. J. and D.M. Spooner : Geographic distribution of wild potato species. Amer. J. Bot., 88, 2101-2112 (2001).

Hochreutiner, B.P.G. : Genresnouveauxet genres discutes de la famille des Malvacees. Candollea, 2, 79-90 (1924).

Jones, P.G., S.E. Beebe, J. Tohme and N.W. Galway: The use of geographical information systems in biodiversity exploration and conservation. Biodivers. Conserv., 6, 947-958 (1997).

Joshi, A.B., V.R. Gadwal and M. W.Hardass: Evolutionary studies in world crops, diversity and change in the Indian sub-continent (Ed. : J.B. Hutchinson). Cambridge University Press, pp. 99-105(1974).

Kursad, ÖZKAN, Özdemir SENTÜRK, Ahmet MERT and Mehmet GÜvenç NEGiZ: Modelling and mapping potential distribution of Crimean juniper (Juniperus excelsa Bieb.) using correlative approaches. J. Environ. Biol., 36, Special Issue, 9-15(2015).

Negi, K.S. and K.C. Pant: Wild species of Abelmoschus medic. (Malvaceae) from Central Himalayan regions of India. J. Bombay Nat. Hist. Soc., 95,148-150 (1998).

Nizar, M. A., N. Dikshit and N. Sivaraj: DIVA-Geographic Information System approaches for assessment of diversity and distribution pattern of Abelmoschus species from Maharashtra, India. Adv. Appl. Res., 6, 28-34 (2014).

Pal, B.P., H.B. Singh and V. Swarup: Taxnomic relationships 
andbreeding possibilities of species of Abelmoschus related to okra (A. esculentus). Bot. Gaz., 113, 455-464 (1952).

Parthasarathy, U., J. George, K.V. Saji, V. Srinivasan, M. S. Madan, Prem Nath Mathur and V.A. Parthasarathy: Spatial analysis for Piper species distribution in India. Plant. Genet. Resour. Newslett. 147,1-5 (2006)

Patil, P., S. Sutar, J. K. Joseph, S. Malik, S. Rao, S. Yadav and K.V. Bhat: A systematic review of the genus Abelmoschus (Malvaceae). Rheedea, 25,14-30 (2015).

Samarajeewa, P.K. and R.M.U. S.K. Rathnayaka: Disease resistance and genetic variation of wild relatives of okra (Abelmoschus esculentus L.). Annals Shri Lanka Depart. Agricult., 6, 167-176 (2004).

Singh, B., M. Rai, G. Kallo, S. Satpathy and K. K. Pandey: Wild taxa of okra (Abelmoschus species) : Reservoir of genes for resistance to biotic stresses. Acta Hortic., 752, 323-328 (2007).

Srinivasa, N. and G. Sugeetha : Field screening of certain okra varieties for resistance against major pests. Insect Environ., 7, 74-76 (2001).
Sunil, N., N. Sivaraj, S. R.Pandravada, V. Kamala, P. Raghuram Reddy and K.S. Varaprasad: Genetic and geographical divergence in horse gram germplasm from Andhra Pradesh, India. Plant Genet. Resour.: Character. Utiliz., 7, 84-87 (2008).

Van Borssum Waalkes, J.: Malaysian Malvaceae revised. Blumea, 14, 1-251 (1966)

Varaprasad, K.S, N. Sivaraj, Mohd. Ismail and S.K. Pareek: GIS mapping of selected medicinal plants diversity in the southeast coastal zone for effective collection and conservation. In:Advances in Medicinal Plants. (Eds. : J. Reddy, K., Bir Bahadur, B. Bhadraiah and M.L.N. Rao.) Universities Press (India) Private Ltd, India., pp. 69-78 (2007).

Varaprasad, K.S., N. Sivaraj, S.R. Pandravada, V.Kamala and N. Sunil: GIS mapping of agrobiodiversity in Andhra Pradesh. Proceedings of Andhra Pradesh Akademi of Sciences. Special Issue on Plant Wealth of Andhra Pradesh, pp. 24-33 (2008).

Velayudhan, K.C., V.A. Amalraj and T.A. Thomas: Collecting germplasm of okra and its wild relatives in Southern India. Indian J. Plant Genet. Resour., 9, 261-268(1996). 